\title{
Phosphorus, iron, manganese, zinc and copper in relation to total flavonoids in medicinal herbs and their infusions originating from Poland, Lithuania and Ukraine
}

\author{
Fosfor, żelazo, mangan, cynk i miedź w relacji do sumy \\ flawonoidów w ziołach leczniczych i naparach pochodzących \\ z Polski, Litwy i Ukrainy
}

${ }^{*}$ Dr farm. Paweł Konieczyński, prof. Marek Wesołowski - Department of Analytical Chemistry, Pharmaceutical Faculty with Subfaculty of Laboratory Medicine, Medical University of Gdansk, Al. Gen. J. Hallera 107, 80-416 Gdańsk, Poland, e-mail: pawelkon@gumed.edu.pl

Keywords: medicinal plants, essential elements, total flavonoids, harvest in Poland, Lithuania and Ukraine, statistical methods Słowa kluczowe: rośliny lecznicze, pierwiastki niezbędne, suma flawonoidów, zbiór w Polsce, Litwie i Ukrainie, metody statystyczne

\section{Abstract}

The aim of the investigation was is to identify differences in an elemental composition ( $\mathrm{P}, \mathrm{Fe}, \mathrm{Mn}, \mathrm{Zn}$ and $\mathrm{Cu}$ ) and their total flavonoids contents of medicinal herbs originating from 9 botanical species, harvested in Poland, Lithuania and Ukraine. Metallic elements were determined by FAAS technique in $\mathrm{mg} \cdot \mathrm{kg}^{-1}$ of dry weight (d. wt) in the order: $\mathrm{Fe}>\mathrm{Mn}>\mathrm{Zn}>\mathrm{Cu}$ in plant materials, and in infusions: $\mathrm{Mn}>\mathrm{Zn}>\mathrm{Fe}>\mathrm{Cu}$. The ratio of water-soluble form to total amount of a metal was as follows: $66.2 \%$ for $\mathrm{Cu}, 22.4 \%$ for $\mathrm{Mn}, 19.7 \%$ for $\mathrm{Zn}$ and $3.8 \%$ for Fe. The contents of $\mathrm{P}$ total, $\mathrm{P}$ inorganic and total flavonoids were determined by UV/Vis spectroscopic methods. By using of analysis of variance, correlation and cluster analyses it has been shown that a significant impact on the diversity of samples has the genetic factor - belonging to a particular botanical species of medicinal plant. The origin of investigated plants proved to be statistically significant only in the case of total Fe concentration, which was higher $(\alpha<0.05)$ for the samples grown in Ukraine. A number of significant correlations was also obtained $(r>0.7)$ between: $\mathrm{P}$ total $-\mathrm{P}$ inorganic, $\mathrm{Mn}$ total $-\mathrm{Mn}$ extractable and $\mathrm{Cu}$ total - $\mathrm{Cu}$ extractable, also $(r>0.5)$ between: total flavonoids - Cu extractable, $\mathrm{P}$ total - Cu total, $\mathrm{P}$ total - Cu extractable, P inorganic $-\mathrm{Zn}$ total. Moreover, comparison of the results of $\mathrm{P}, \mathrm{Fe}$, $\mathrm{Mn}, \mathrm{Zn}$ and $\mathrm{Cu}$ determination in infusions of medicinal plants with the norms of RDA has shown that a significant amount (several percentage) of $\mathrm{Mn}$ and $\mathrm{Cu}$ can be supplemented to human organism with 2 cups of infusions prepared from Helichrysi inforescentia and Hyperici herba.

(c) IOŚ-PIB

\section{INTRODUCTION}

Herbal drugs are very popular among populations of many European countries. The herbal enterprises settled in countries of Central-Eastern Europe deliver plant materials for medicinal purposes for their own societies, and also for export. It is also known that medicinal plants can be cultivated or are being collected from natural areas, and their quality control has received growing attention [World Health Organization report 2003, Schippmann et al. 2006].

\section{Streszczenie}

Celem badań była identyfikacja różnic w składzie pierwiastkowym ( $\mathrm{P}, \mathrm{Fe}, \mathrm{Mn}, \mathrm{Zn}$ i Cu) oraz w zawartości sumy flawonoidów w ziołach leczniczych pochodzących od 9 gatunków botanicznych, zebranych w Polsce, Litwie i Ukrainie. Pierwiastki metaliczne oznaczono techniką FAAS (mg $\mathrm{kg}^{-1}$ s.m.) w następującym porządku: $\mathrm{Fe}>\mathrm{Mn}>\mathrm{Zn}>\mathrm{Cu}$ w suchej masie surowców, oraz w naparach: $\mathrm{Mn}>\mathrm{Zn}>\mathrm{Fe}>\mathrm{Cu}$. Stosunek form rozpuszczalnych w wodzie do całkowitej zawartości pierwiastków był następujący: $66,2 \%$ dla $\mathrm{Cu}, 22,4 \%$ dla $\mathrm{Mn}, 19,7 \%$ dla Zn i $3,8 \%$ dla Fe. Zawartość $\mathrm{P}$ całkowitego, nieorganicznego oraz sumę flawonoidów oznaczono techniką spektrofotometrii UV/Vis. Dzięki użyciu analizy wariancji, korelacji i skupień wykazano, że istotny wpływ na zróżnicowanie próbek wywierał czynnik genetyczny - przynależność do poszczególnych gatunków botanicznych roślin leczniczych. Natomiast oznaczono statystycznie wyższy $(\alpha<0.05)$ poziom $\mathrm{Fe}$ całkowitego $w$ próbkach rosnących na Ukrainie. Otrzymano też szereg istotnych statystycznie korelacji ( $r>0.7)$ pomiędzy: $P$ całkowitym - P nieorganicznym, $\mathrm{Mn}$ całkowitym - Mn rozpuszczalnym oraz Cu całkowita - $\mathrm{Cu}$ rozpuszczalną, również ( $r>0.5)$ pomiędzy: sumą flawonoidów - Cu rozpuszczalną, P całkowitym - Cu całkowitą, P całkowitą Cu rozpuszczalną, $P$ nieorganicznym - Zn całkowitym. Ponadto, porównanie wyników oznaczenia $\mathrm{P}, \mathrm{Fe}, \mathrm{Mn}, \mathrm{Zn}$ i Cu w naparach z roślin leczniczych z normami RDA wykazało, że istotne ilości (kilkanaście procent) Mn i Cu mogą być dostarczane do organizmu ludzkiego poprzez wypijanie 2 filiżanek naparu otrzymanego z Helichrysi inforescentia i Hyperici herba.
Medicinal plant composition has been studied for numerous purposes. Secondary metabolites were analysed to select the plants with the optimum concentration of biologically active substances, for instance, flavonoids [Rohman et al. 2010, Marinova et al. 2005, Barros et al. 2012], also elemental contents have been characterised in several studies [Tokalioglu 2012, Karadas and Kara 2012, Arceusz et al. 2011, Razic et al. 2006, Mohanta et al. 2003]. The problem of influence of plant species 
and origin of herbs from various geographical location on the contents of essential elements in medicinal plants was studied, too [Konieczynski and Wesolowski 2007, Konieczynski et al. 2011].

Therefore the aim of this research is to identify differences in an elemental composition ( $\mathrm{P}, \mathrm{Fe}, \mathrm{Mn}, \mathrm{Zn}$ and $\mathrm{Cu}$ ) and total flavonoids contents in medicinal herbs originating from nine different botanical species, harvested in Poland, Lithuania and Ukraine.

\section{MATERIAL AND METHODS OF STUDY}

Within the study 53 samples of medicinal herbs harvested in Poland, Lithuania and Ukraine, originating from 9 botanical plant species were analysed. They are listed below (sample numbers are given in parentheses): Crataegi inflorescentia (1-4), Crataegi fructus (5-8), Equiseti herba (9-15), Helichrysi inflorescentia (16-21), Violae herba (22-25), Hyperici herba (26-31), Tiliae inflorescentia (32-37), Sambuci flos (38-43), Polygoni avicularis herba (44-49) and Matricariae flos (50-53).

The plant samples were ground in a Knifetec sample mill 1095 (Höganäs, Sweden) and were kept in polyethylene containers up to the analyses. In order to prepare the plant materials for determination of total concentrations of the studied elements, the herbal samples were digested by microwave-assisted digestion procedure (UniClever BM-1z, Plazmatronika Wrocław, Poland). For carrying out the analysis of water-soluble forms of the elements, as well as for determination of the sum of flavonoids, single extraction by hot distilled water was used. Distilled water obtained in double-distillation system (Heraeus Quarzglas, Germany) was used throughout.

Spectrophotometric UV/Visible method based on phosphomolybdate blue was applied for total $\mathrm{P}$ and water-extractable $\mathrm{P}$ determinations using SP-870 spectrophotometer (Metertek, South Korea), whereas flame-atomic absorption spectroscopy applying A250 plus spectrometer (Varian, Australia) was used to determine $\mathrm{Fe}, \mathrm{Mn}, \mathrm{Zn}$ and $\mathrm{Cu}$ concentrations both in digests obtained from plant samples, and in aqueous extracts (teas) prepared from the studied herbal materials [Konieczynski and Wesolowski 2007]. Total flavonoids content was determined by spectrophotometric method with $\mathrm{AlCl}_{3}$ at the analytical wavelength $510 \mathrm{~nm}$ using the same apparatus as for $\mathrm{P}$ determinations [Zhishen et al., 1999]

\section{RESULTS AND DISCUSSION}

Based on the results it was shown that mean total flavonoids content in all studied samples was equal to $50.07 \mathrm{mg} \cdot \mathrm{g}^{-1}$ of dry plant weight (d. wt). The lowest amount, $22.43 \mathrm{mg} \cdot \mathrm{g}^{-1} \mathrm{~d}$. wt was determined in $V$. herba (sample 25), and the highest, $128.33 \mathrm{mg} \cdot \mathrm{g}^{-1}$ d. wt in $H$. herba (sample 30). The mean values of total flavonoids contents in particular botanical plant species are presented in Fig. 1.

The infusions prepared from $H$. herba can be characterised as having the highest level of total flavonoids $-90.84 \mathrm{mg} \cdot \mathrm{g}^{-1} \mathrm{~d}$. wt, and the lowest amount $-16.06 \mathrm{mg} \cdot \mathrm{g}^{-1} \mathrm{~d}$.wt was found in infusions from $V$. herba. The results of ANOVA calculations confirm statistically significant differences $(\alpha<0,05)$ in mentioned above

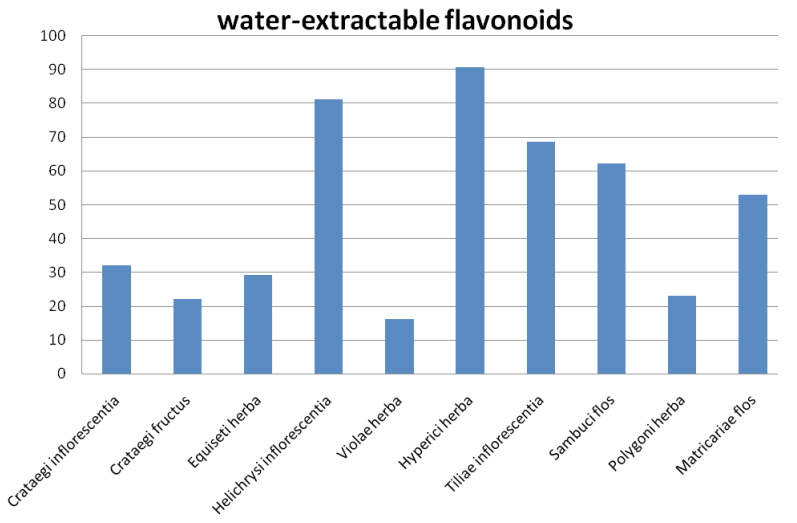

Fig. 1. Total flavonoids contents $\left[\mathrm{mg} \cdot \mathrm{g}^{-1} \quad \mathrm{~d}\right.$. wt $]$ determined in various botanical plant species

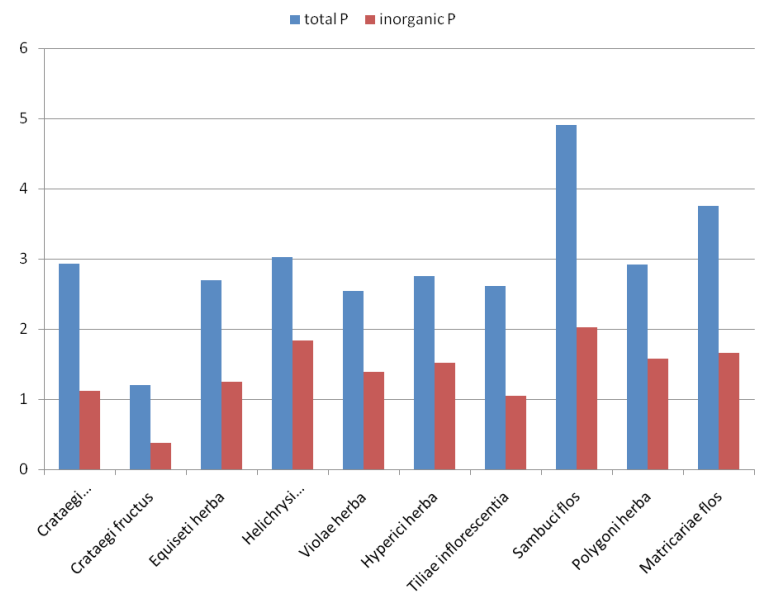

Fig. 2. Total and water-extractable phosphorus $\left[\mathrm{mg} \cdot \mathrm{g}^{-1}\right.$ d. wt $]$ in the samples of medicinal herbs.

levels among herbs from various plant species. Moreover, Tukey test indicated the significant difference occurring among plant samples from the following plant species: Polygonum, Helichrysum, Hypericum, Tilia and Sambucus.

Total phosphorus (total P) mean concentration was determined in all samples as $2.98 \mathrm{mg} \cdot \mathrm{g}^{-1} \mathrm{~d}$. wt, whereas water-extractable form of $\mathrm{P}\left(\mathrm{P}-\mathrm{PO}_{4}\right)$ as $1.42 \mathrm{mg} \cdot \mathrm{g}^{-1} \mathrm{~d}$. wt. The level of phosphorus forms is differentiated taking into account the origin of the studied samples from different plant species, as shown in Fig. 2. The highest mean concentration of total $P-4.90 \mathrm{mg} \cdot \mathrm{g}^{-1} \mathrm{~d}$. wt was found in $S$. flos, and the lowest $-1.20 \mathrm{mg} \cdot \mathrm{g}^{-1} \mathrm{~d}$. wt in C. fructus. Similarly, in the same plant materials water-extractable inorganic $P$ was determined, $2.02 \mathrm{mg} \cdot \mathrm{g}^{-1} \mathrm{~d}$. wt in $S$. flos, and $0.38 \mathrm{mg} \cdot \mathrm{g}^{-1}$ d. wt in C. fructus, respectively. On average, water-extractable inorganic $\mathrm{P}$ constitute $48 \%$ of total level of that element in all studied samples. This is compatible with the previous studies of water-extractable inorganic $P$ in medicinal plant infusions [Konieczynski et al. 2011]. The results of ANOVA test revealed that the difference among plant samples are statistically significant $(\alpha<0,05)$, and the use of Tukey's test has proven that significant differences in total and inorganic $P$ levels occur among the plants from Crataegus, Equisetum, Viola, Polygonum, Helichrysum, Hypericum, Tilia, Chamomilla and Sambucus botanical species. 
Table 1. Results of correlation analysis. Correlation coefficients $(r)$ statistically significant $(\alpha<0,05)$ are printed in bold

\begin{tabular}{|c|c|c|c|c|c|c|c|}
\hline & Total flav. & $\mathbf{P}$ & P-PO & $\mathrm{Zn}$ & Zn-ext & $M n$ & $\mathrm{Cu}$ \\
\hline $\mathrm{P}-\mathrm{PO}_{4}$ & 0.34 & 0.78 & 1.00 & & & & \\
\hline $\mathrm{Fe}$ & -0.37 & 0.15 & 0.15 & & & & \\
\hline Fe-ext & -0.04 & 0.14 & 0.15 & & & & \\
\hline $\mathrm{Zn}$ & 0.19 & 0.41 & 0.63 & 1.00 & & & \\
\hline Zn-ext & 0.48 & -0.12 & 0.24 & 0.61 & 1.00 & & \\
\hline $\mathrm{Mn}$ & 0.36 & 0.03 & 0.17 & 0.29 & 0.53 & 1.00 & \\
\hline Mn-ext & 0.42 & 0.01 & 0.28 & 0.50 & 0.68 & 0.84 & \\
\hline $\mathrm{Cu}$ & 0.37 & 0.65 & 0.57 & 0.13 & -0.08 & 0.01 & 1.00 \\
\hline Cu-ext & 0.56 & 0.57 & 0.55 & 0.19 & 0.32 & 0.11 & 0.80 \\
\hline
\end{tabular}

Total flav. $=$ total flavonoids contents; ext $=$ water-extractable form of an element

Table 2. Contribution to the RDA norms after drinking 2 cups of herbal infusion (500 mL)

\begin{tabular}{|c|c|c|c|c|c|c|}
\hline \multirow{2}{*}{ Herbal remedy } & $\mathbf{P}$ & $\mathbf{M n}$ & $\mathbf{C u}$ & $\mathbf{F e}$ & $\mathbf{Z n}$ \\
\hline Crataegi inflorescentia & & & & & \\
\hline Crataegi fructus & 2.76 & 5.07 & 7.99 & 0.82 & 1.54 \\
\hline Equiseti herba & 0.96 & 0.69 & 4.19 & 1.41 & nd \\
\hline Helichrysi inflorescentia & 3.11 & 9.63 & 5.58 & 1.08 & 0.38 \\
\hline Violae herba & 4.64 & 18.57 & 12.54 & 1.39 & 3.05 \\
\hline Hyperici herba & 3.27 & 14.27 & 9.74 & 1.74 & 2.2 \\
\hline Tiliae inflorescentia & 3.83 & 12.13 & 13.08 & 1.03 & 2.2 \\
\hline Sambuci flos & 2.57 & 8.88 & 12.92 & 1.07 & nd \\
\hline Polygoni avicularis herba & 5.08 & 5.27 & 15.62 & 1.5 & 0.9 \\
\hline Matricariae flos & 3.86 & 4.61 & 12.12 & 1.16 & 0.31 \\
\hline
\end{tabular}

nd - not detected

In the case of studied metallic elements, it can be stated that the analysed plant samples contained them in the following order: $\mathrm{Fe}>\mathrm{Mn}>\mathrm{Zn}>\mathrm{Cu}$ in $\mathrm{mg} / \mathrm{kg}^{-1} \mathrm{~d}$. wt, and in infusions: $\mathrm{Mn}>\mathrm{Zn}$ $>\mathrm{Fe}>\mathrm{Cu} \mathrm{mg} / \mathrm{kg}^{-1} \mathrm{~d}$. wt. The ratio of water-soluble form to total level of a metal was as follows: $66.2 \%$ for $\mathrm{Cu}, 22.4 \%$ for $\mathrm{Mn}$, $19.7 \%$ for $\mathrm{Zn}$ and $3.8 \%$ for Fe. These results are concurrent with those reported by others [Tokalioglu 2012, Karadas and Kara 2012, Razic et al. 2006, Mohanta et al. 2003]. ANOVA calculation allows to state that the differences in metallic elements level in the studied plant samples are statistically significant $(\alpha<0,05)$, and application of Tukey's test enabled to reveal that these differences are important for all botanical plant species. However, taking into consideration the origin of studied medicinal plants from various countries, it was found that only in the case of total Fe content, it was statistically higher $(\alpha<0.05)$ for the samples grown in Ukraine. The reason for this difference is not easy to explain, perhaps the level of Fe in Ukrainian soils was higher than in other locations, but this metal was not assayed in soil samples. The results of correlation analysis are presented in Table 1. Among 55 calculated correlations, there are 22 statistically significant relations $(\alpha<0.05)$. It is possible to indicate high correlations $(r>0.7)$ between $\mathrm{P}$ total $-\mathrm{P}$ inorganic, Mn total $-\mathrm{Mn}$ extractable and $\mathrm{Cu}$ total $-\mathrm{Cu}$ extractable, also $(r>0.5)$ between: total flavonoids - $\mathrm{Cu}$ extractable, $\mathrm{P}$ total $-\mathrm{Cu}$ total, $\mathrm{P}$ total $-\mathrm{Cu}$ extractable, $\mathrm{P}$ inorganic - $\mathrm{Zn}$ total. High correlation between total $P$ and inorganic $P$ was found in our earlier studies [Konieczynski and Wesolowski 2007, Konieczynski et al. 2011], and the relation between flavonoid contents and metallic elements can indicate on their participation in the same metabolic pathways in medicinal plants, moreover $\mathrm{Cu}$ as electro-active metal can interact with flavonoid compounds [Konieczynski, 2015].

Analysing the obtained results in context of delivery of essential elements to human organism, it was assumed that a consumer drinks daily two cups of herbal infusion $(500 \mathrm{ml})$. The results of 
the calculation are shown in Table 2. On average, 2 cups of herbal infusions from the studied medicinal plants deliver $3.4 \%$ of the recommended dietary allowances [National Academy of Sciences, 2004] for P. Taking into account the bioavailable level of essential metallic elements, it is possible to notice that a significant amount (several percentage) of $\mathrm{Mn}$ and $\mathrm{Cu}$ can be supplemented to human organism with two cups of infusions prepared from $\mathrm{H}$. inforescentia and $H$. herba. The infusions prepared from other plant species deliver rather lower amounts (several percents) of metallic elements in comparison with dietary norms.

\section{CONCLUSIONS}

By analysis of total flavonoids together with metallic elements and $\mathrm{P}$ contents it was possible to detect the differences occurring among medicinal plant species originating from Poland, Lithuania

\section{REFERENCES AND LEGAL ACTS}

ARCEUSZ A., WESOLOWSKI M., RADECKA I. 2011. Macroand micro-elements in some herbal drugs raw materials and their water extracts consumed in Poland. Central European Journal of Chemistry 9: 917-924.

BARROS L., DUENAS M., CARVALHO A.M., FERREIRA I.C.F.R. 2012. Characterization of phenolic compounds in flowers of wild medicinal plants from Northeastern Portugal. Food and Chemical Toxicology 50: 1576-1582.

KARADAS C., KARA D. 2012. Chemometric approach to evaluate trace metal concentrations in some spices and herbs. Food Chemistry 130: 196-202.

KONIECZYNSKI P., WESOLOWSKI M. 2007. Determination of zinc, iron, nitrogen and phosphorus in several botanical species of medicinal plants. Polish Journal of Environmental Studies 16: 785-790.

KONIECZYNSKI P., WESOLOWSKI M., RADECKAI., RAFALSKI P. 2011. Bioavailable inorganic forms of essential elements in medicinal plants from Northern Poland. Chemical Speciation and Bioavailability 23: 61-70.

KONIECZYNSKI P. 2015. Electrochemical fingerprint studies of selected medicinal plants rich in flavonoids. Acta Poloniae Pharmaceutica - Drug Research 72: 655-661.

MARINOVA D., RIBAROVA F., ATANASSOVA M. 2005. Total phenolics and total flavonoids in Bulgarian fruits and vegetables. Journal of the University of Chemical Technology and Metallurgy 40: 255-260.

MOHANTA B., CHAKRABORTY A., SUDARSHAN M., DUTTA R.K., BARUAH M. 2003. Elemental profile in some common medicinal plants of India. Its correlation with traditional therapeutic usage. Journal of Radioanalytical and Nuclear Chemistry 258:175-179. and Ukraine. Due to the application of ANOVA statistically significant differences among the studied plant samples were revealed, and the main reason for their differentiation appeared to be the botanical plant species. The origin of investigated plants proved to be statistically significant only in the case of total $\mathrm{Fe}$ concentration, which was higher $(\alpha<0.05)$ for the samples grown in Ukraine.

\section{ACKNOWLEDGEMENTS}

This paper was supported by the Ministry of Science and Higher Education of the Republic of Poland from the qualitypromoting subsidy programme (ST-15). The Authors wishes to thank dr Viktorija Vastakaite for kind delivery of the plant samples from Lithuania, and dr Oleg M. Koshoviy for the samples from Ukraine.

NATIONAL ACADEMY OF SCIENCES 2004. Dietary Reference Intakes (DRIs): Recommended intakes for individuals, Elements. Available from http:/www.nap.edu.

RAZIC S.S., DOGO S.M., SLAVKOVIC L.J. 2006. Multivariate characterization of herbal drugs and rhizosphere soil samples according to their metallic content. Microchemical Journal 84: 93-101.

ROHMAN A., RIYANTO S., YUNIARTI N., SAPUTRA W.R., UTAMI R., MULATSIH W. 2010. Antioxidant activity, total phenolic, and total flavonoid of extracts and fractions of red fruit (Pandanus conoideus Lam). International Food Research Journal 17: 97-106.

SCHIPPMANN U., LEAMAN D., CUNNINGHAM A.B. 2006. A comparison of cultivation and wild collection of medicinal and aromatic plants under sustainability aspects. In: BOGERS R.J., CRAKER L.E., LANGE D., (Eds.), Medicinal and Aromatic Plants: Agricultural, Commercial, Ecological, Legal, Pharmacological and Social Aspects, Springer, 75-96.

TOKALIOGLU S. 2012. Determination of trace elements in commonly consumed medicinal herbs by ICP-MS and multivariate analysis. Food Chemistry 134: 2504-2508.

WHO guidelines on good agricultural and collection practices (GACP) for medicinal plants 2003, World Health Organization, Geneva.

ZHISHEN J., MENGCHENG T., JIANMING W. 1999. The determination of flavonoid contents in mulberry and their scavenging effects on superoxide radicals. Food Chemistry 64: 555-559. 